\title{
Impact of Leadership Styles on Employees' Organizational Commitment in Lithuanian Manufacturing Companies
}

Ilona Bučiūnienè, Vida Škudienė*

\section{Abstract:}

This article investigates the relationship between employees' organizational commitment dimensions and leadership styles in Lithuanian manufacturing companies. The findings of the study reveal positive correlations between a transformational leadership style and affective and normative employee commitments. A laissez-faire leadership style was found to be negatively associated with employees' affective commitment.

Keywords: Leadership styles, Organizational commitment, Manufacturing companies, Lithuania.

JEL:

\section{Introduction}

The changing demographics of the work market with baby boomers nearing retirement - has caused managers in the US and Europe to rethink work force shortage issues. Lithuania and other new members of the European Union are experiencing an even stronger effect from this phenomenon because of the workforce flow to more developed European Union countries. How to retain employees and keep them committed to an organization remains one of the most significant issues in management today. Therefore, a great deal of attention recently has been given to the study of commitment to organization (Mowday, Porter \& Steers, 1979; Allen \& Meyer, 1990; Jaussi, 2007). However, few studies have tested the relationship between leader behaviors and employee commitment. Even fewer studies have considered this issue in Lithuania.

The research findings (Taylor, 1998; Glisson and Durick, 1988), as well as leadership theories (behavior, cognitive, and social interaction) allow us to make the assumption that employee commitment to an organization is affected by leader behavior. However, many issues regarding this interrelationship remain unclear. For example, are some leadership styles more appropriate than others in enhancing employees' organizational commitment? Can an immediate supervisor improve the employees' commitment by adopting an appropriate leadership style?

The object of research is leadership styles and employee commitment to an organization.
The aim of this paper is to investigate the relationship between leadership styles and employee organizational commitment.

Research methodology. A quantitative descriptive research method, a questionnaire survey, was employed to obtain measures of leadership style and employee commitment. Middle-level managers from five Lithuanian manufacturing companies participated in the study. The survey data was processed using a SPSS statistical package (version 13). The relationship between the rank variables was checked by calculating Spearman's correlation coefficient (p).

\footnotetext{
* Bučiūnienè

ISM University of Management and Economics. Kaunas E. Ožeškienés

st. 18 Kaunas 44254

Lithuania

e-mail:ilona.buciuniene@ism.It

*Škudienè

ISM University of Management and Economics. Kaunas E. Ožeškienés

st. 18 Kaunas 44254

Lithuania

e-mail:vida.skudiene@ism.lt
} 
The research findings demonstrate the positive relationship between a transformational leadership style and affective commitment. Employee satisfaction with their supervisors is reported to have significant effects on employees' affective and normative commitments. The findingsofthisstudyrevealthattransformationaltransactional leadership is more important than transactional leadership in relation to followers' organizational commitment. Laissezfaire leadership produces negative impacts on affective commitment.

Such findings clearly demonstrate the important role of transformational leadership and indicate that organizations should endeavor to nurture transformational leadership qualities among their leaders.

\section{Theoretical Framework of Employees' Organizational Commitment}

R.T. Mowday, L.W. Porter and R.T. Steers (1979) defined organizational commitment as a strong belief in the organization's goals and values and a willingness to exert considerable effort on behalf of the organization. Commitment to organization is linked to very important work-related factors: employee turnover, absenteeism and performance (Mowday, Steers \& Porter, 1979; Romzek, 1990; Ward et al., 1995; Walton, 1985).

The fact that there is no agreement among organizational behavior researchers on the definition of commitment indicates that commitment may be multidimensional, having both attitudinal and behavioral components (Meyer and Allen, 1993). The attitudinal commitment, according to Jaussi (2007), has three dimensions: positive affect for the organization, identification with the organization and willingness to exert effort on behalf of the organization. Behavioral commitment emphasizes that commitment is grounded in behavior resulting primarily from perceived constraints on a worker's ability to leave the organization and from choices that bind him to the organization (Salancik, 1977).

Commitment as a function of beliefs about organization is described by L.W. Porter, R.M. Steers, R.T. Mowday \& R. Boulian (1974). They define commitment to organization as the relative strength of the employees' identification with their organization. According to their definition, organizational commitment has three components: a strong belief in and acceptance of the organization's goals and values; a willingness to exert considerable effort on behalf of the organization; and a strong intention or desire to remain with the organization.

Commitment as a function of behavior according to A.M. Sulimanetal.(2000) is definedasemployees'attitudetowards the commitment to the organization as an investment of time spent in the organization, friendly relationships with the coworkers, saved pension funds, etc. In this case it is not beneficial for employees to leave the organization because of the "sunk cost." H.S. Becker (1960) claims that employees' commitment is their association with the organization that occurs when employees calculate the costs of leaving the organization.

Building on the work of L. W. Porter et al., (1974), J. P. Meyer and N. J. Allen (1984) conceptualized commitment as a multidimensional concept consisting of three distinct psychological states: emotional attachment to the organization (affective commitment), recognition of the costs associated with leaving the organization (continuance commitment), and perceived obligation to remain with the organization (normative commitment).

However, inconsistencies across the formulations of organizational commitment exist, as scholars have characterized the construct of organizational commitment dimensions differently. For example, C. O'Reilly and J. Chatman (1986) define organizational commitment as a concept consisting of three main components: agreement associated with a certain benefit, identification associated with a need to be a member of the organization, and internalization perceived as employee's values identification with the organization's values. Moreover, J. P. Meyer et al., (2001) noticed differences in scholars' definitions of organizational commitment dimensions, formulations and components.

Affective commitment according to N.J.Allen and J.P.Meyer (1990), is an emotional attachment to an organization in which an employee "identifies with and enjoys membership in the organization." Thus, affective commitment encompasses at least three dimensions: development of an emotional involvement with an organization, identification with an organization, and a desire to remain its member.

Continuance commitment is the second organizational commitment construct defined by N.J. Allen and J.P.Meyer (1990) basedonH.S.Becker's (1960) side-bettheory.ltisbased on the idea that the investments, or side bets, an employee makes in an organization, such as time, job effort, and the development of work friendships, organization-specific skills, and political deals, constitute sunk costs that diminish the attractiveness of external employment alternatives (Jaros, et al., 1993). The employee feels compelled to commit to the organization because the monetary, social, psychological, and other costs associated with leaving are high. N.J. Allen and J.P.Meyer (1990) advanced the concept of continuance commitment as a form of psychological attachment to an employing organization that reflects the degree to which an individual experiences a sense of being locked in place because of the high costs of leaving. This perception determines an employee's decision to stay in an organization and save the created benefit.

Normative commitment is the third organizational commitment dimension associated with an employee's sense of duty to stay in an organization. D. M. Randall and M. P. Driscoll (1997) defined normative commitment as an employee's moral commitment that manifests itself when 
an organization provides moral and financial support for the employee's development.

Our view is that all three organizational commitment dimensions are caused by different reasons. Considerable disagreement remains over the concept of organizational commitment.Furthermore,commitmentresearchersremain divided over the dimensionality of attitudinal commitment and the nature of organizational commitment.

\section{Dimensions of Leadership Styles}

Although the concept of leadership has been used since the beginning of the 19th century, there has been no consistent agreement upon a method to measure the nature and consequences of successful leadership (Stogdill, 1974). J. M. Burns (1978) claims that leadership is the most observed but the least understood phenomenon in the world. Although many authors have studied this issue, there is no consensus regarding its definition. Leadership researchers in recent years have accumulated a large body of leadership definitions, which were structured by M. M. Chemers (1997). He designed the so-called"leadership definitions umbrella," which defines leadership as "a social influence process, during which one individual enables to reassure support and assistance to other individuals in order to achieve mutual goals." M. M. Chemers (1997) also found that the leadership phenomenon was not scientifically researched until the beginning of the 20th century. $B$. M. Bass (1985) claimed that the first theorists attempted to identify leadership using only theoretical methods. No attempt was made to explore the relationship between individual and situation variables. This was, according to B. M. Bass (1985), the main reason why no successful leadership theories were developed. Until recently, research on leadership has taken several approaches. Most research can be classified into one of four major categories (Rowden, 1999): trait approaches, situational approaches, power-influence approaches, and behavioral approaches (Yukl, 1989). However, no one method has been found to be very effective in all situations (Bass, 1990). Recently, the focus of leadership has shifted from traditional or transactional models of leadership to a new genre of leadership theories, with an emphasis on transformational leadership (Bass, 1985). The whole model of leadership presented by B. J. Avolio and B. M. Bass (1991) reveals three main leadership styles: transformational, transactional and laissez-faire. The components of transformational and transactional leadership have been identified in a variety of ways, including through the use of factor analyses, observations, interviews, and descriptions of a follower's ideal leader. Using the Multifactor Leadership Questionnaire (MLQ-Form 5X; Avolio and Bass, 2002),
B. J. Avolio, B. M. Bass, and D. I. Jung (1999) and J. Antonakis (2001) identified the distinct components of transformational leadership: idealized influence, inspirational motivation, intellectual stimulation, and individualized consideration. Although multifactor theory is probably the most widely cited and comprehensive theory, leadership is often conceptualized within behavioral domains varying from non-leadership, or laissez-faire, to transactional leadership, which hinges on rewards and punishments, to transformational leadership, which is based upon attributed and behavioral charisma (Bass and Avolio, 1993). Transformational leaders develop relationships with their followers that go beyond pure economic and social exchange (Bass, 1985). Studies have linked transformational leadership to high levels of effort (Seltzer and Bass, 1990), satisfaction with the leader (Bass, 1985), and trust in the leader (Bass, 1985). R.J.Deluga (1992) and J.M. Howell and K. E. Hall-Merenda (1999) demonstrated that transformational leadership is significantly related to high quality exchanges. Findings in transactional leadership show mixed results. Contingent reward leadership has been found in many cases to be highly correlated to transformational leadership (Avolio et al., 1999). In general, active leadership is found to be plausibly more effective than passive leadership. However, J. M. Howell and B. J. Avolio (1993) argued that if the predominant style of the leader is to take corrective action, such behavior is expected to have a negative impact on followers' performance over time. With laissezfaire leadership being associated with dissatisfaction, unproductiveness and ineffectiveness (Deluga, 1992), it is possible that followers do not hold as much respect for their supervisors and that this style of leadership is inappropriate (Hartog et al., 1997).

\section{Relationship between Organizational Commitment and Leadership Styles}

Previous research has devoted a great deal of attention to the relationship between leadership behavior and organizational commitment. The findings in this area, however, are not entirely consistent. Several studies found a positive relationship between the two variables (Kraut, 1970; Newman, 1974; Alley and Gould, 1975; Porter et al., 1976; etc.). In contrast, C.A.O'Reilley and K.H. Roberts (1978), R. Hampton et al., 1986) reported no linkages between organizational commitment and leadership styles, whereas J.G.Hunt and V.K.C.Liesbscher (1973) discovered a negative association between these two variables.

J. Morris and R.M. Steers (1980) have linked leadership behavior to employees' organizational commitment and found positive correlations between high respect for leaders, high hierarchical structure level and organizational commitment. A.P. Brief, R.J. Aldag, and R.A. Wallen (1976) investigated police officers' organizational commitment and reported high positive relationships between respect 
for their supervisors and organizational structuring level. J. Morris and R.M. Steers (1985), S. Parasuraman and S. Nachman (1987), C.E. Michaels and P.E. Sector (1982) also found positive relations between leaders' behavior and their subordinates' commitment. A.E. Reichers (1985) suggested that organizational commitment is a set of commitments to an organization's shareholders, leaders, customers, and coworkers. However, A.E. Reichers (1985) identified only one strong positive correlation between commitment and higher level leaders' goals and values. T.E. Becker (1992) found that employees' commitment to their supervisors and work groups is more expressed than general commitment to their organization.

B.M.Bass and B.J.Avolio (1993) claimed that organizations have a kind of culture, which is represented by the leaders who use transactional or transformational leadership styles. According to their findings, transactional culture creates only short-term commitment, whereas transformational culture creates long-term commitment. D.S. Carlson and P.L. Perrewe (1995) argued that when transformational leadership is enacted, members of organizations no longer seek merely self-interest, but that which is beneficial to the organization as a whole.

L. Simon (1994) studied transformational leadership impact on organizational commitment and found that transformational leadership has a positive linkage with normative and affective commitment. On the other hand, a negative relationship was found between transformational leadership and continuance commitment. P. Bycio and his colleagues (1995) reported a lower but positive relationship between normative commitment and transformational leadership, whereas transformational leadership exhibited strong positive relationships with affective commitment. However, they failed to find the hypothesized relationship between transactional leadership and commitment. The findings of F. Brown and N. Dodd (1999) indicated a strong correlation between transformational leadership dimensions and affective commitment, a weaker but still strong positive correlation with normative commitment and no relationship with continuance commitment. A negative relationship was found between transactional leadership dimensions and affective and normative commitments, and a statistically significant correlation found with continuance commitment.

Overall,thescientificliteratureandresearchanalysissurvey reveal that there is no consensus regarding relationships between employee commitment and leadership styles.

\section{Hypotheses Development}

N.J. Allen and J.P. Meyer (1990) define affective commitment as an employee's emotional attachment to, identification with and involvement in the organization. Identification with the organization occurs when an employee identifies his/her values with the organization's values and builds personal and social identification with the mission and goals of the organization. Previous research indicates that transformational leadership's attitude dimension, such as idealized influence, occurs when leaders are admired, respected and trusted, and they consider the follower's needs over their own. Moreover, the transformational leadership behavior dimension occurs when leaders share their values and belief with their followers and allows them to understand the importance of their decisions (Bass \& Avolio, 1993). Based on these considerations' synthesis, the hypothesis tested in this study is proposed:

Hypothesis 1: Transformational leadership style is positively related to employee affective commitment.

B.S. Romzek (1990) defines the continuance commitment dimension as a transactional relationship. He claims that an employee recognizes the costs (employee's investment in an organization) and compares what benefit $s / h e$ will receive if $s / h e$ continues the activity and what the employee is going to lose if $s /$ he leaves it. B.S. Romzek's (1990) definition of continuance commitment could be interpreted as commitment associated with exchange between the employee's assessment of costs and the organization's inducement possibilities. Meanwhile, the authors (Burns, 1978; Bass, 1985) and researchers of recent leadership theories (Owen et al., 2004) describe many kinds of valuable exchange in politics or business organizations as related to transactional leadership. Therefore, the conclusion may be drawn that transactional leadership and continuance commitment are closely related. Given the above considerations, the following hypothesis is proposed:

Hypothesis 2: A transactional leadership style is positively related to employee continuance commitment.

S.J.Jaros et al.,(1993) suggest that normative commitment refers to the employee's feelings of obligation and need to work. Not surprisingly, these kinds of feelings are aroused by transformational leader characteristics. According to H. Owen et al., (2004) a leader should be aware of his/her and employees' values, to take into consideration mutual interests, to distribute power equally, to not seek only shortterm goals and stakeholders' satisfaction and to pursue and meet all shareholders' needs. Moreover, normative commitment is a long-term construct that is created through transformational leadership dimensions (Bass and Avolio, 1993). On the basis of these insights the following hypothesis is put forth:

Hypothesis 3: A transformational leadership style is positively related to employee normative commitment.

Prior evidence indicates that laissez-faire leadership is less beneficial to employee affective commitment (Bass, 1990; Bass and Avolio, 1993). Therefore, the following hypothesis is proposed:

Hypothesis 4: A laissez-faire leadership style is negatively related to employee affective commitment. 
FollowingB.M.BassandB.J.Avolio(1993),atransformational leadership style is linked to a leader's charisma, inspirational motivation, individualized consideration, and intellectual stimulation. Meanwhile, continuance commitment according to N. J. Allen and J.P. Meyer (1990) is correlated with employees' perceived "loss." Taking into account the above considerations, the following assumption could be formed: either transformational leadership does not correlate with continuance commitment, or it is negatively correlated with it.This assumption responds to suggestions made by L.Simon (1994) that transformational leadership is negatively related to continuance commitment. Therefore, the following hypothesis is proposed:

Hypothesis 5: A transformational leadership style is negatively related to employee continuance commitment.

Several studies (Reichers, 1985; Becker, 1992) have reported that employees express commitment to their leaders more than to their organization or their commitment to an organization is based on their satisfaction with their leaders' goals and values. J.P. Meyer and N.J.Allen (1997) claim that employees' commitment to organization measures employees' commitment to their leaders. Given the above considerations, the following hypotheses are proposed:

Hypothesis 6: Satisfaction with an immediate supervisor is positively related to employees' affective commitment.

Hypothesis 7: Satisfaction with an immediate supervisor is positively related to employees' normative commitment.

The hypothetical model shown in Figure 1 is consistent with the arguments and hypotheses presented above.

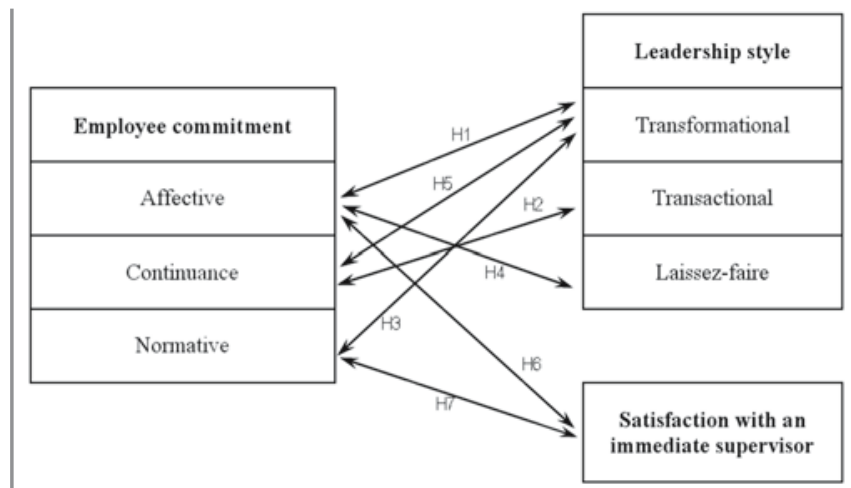

Figure 1. The hypothetical model of relationship between leadership styles and employees committment

\section{Research Methodology}

A quantitativedescriptiveresearch method-aquestionnaire survey - was employed to test the above hypotheses. Given the relativelysmall size of the employeepopulation, the survey included the total population of 224 middle level managers from five manufacturing companies in Lithuania. A total of 191 usable questionnaires were obtained, representing an 80 $\%$ response rate. Standard deviation coefficient was 0,027 or

\section{$2,7 \%$.}

The survey questionnaire was composed of the following parts: introduction; questions designed to identify leadership style (adapted from B.M. Bass and B.J. Avolio (1993) MLQ (Multifactor Leadership Questionnaire)) 5X short form; questions designed to measure employees' commitment to an organization (adapted from questionnaire by J.P. Meyer and N.J. Allen (1997)); and questions designed to measure satisfaction with an immediate supervisor.

The survey data was processed using a SPSS statistical package (version 13). The relationship between the rank variables was checked by calculating Spearman's correlation coefficient

\section{Research Findings}

The descriptive statisticsand correlation matrix for the items maybe found in Table1. Asseen from the results, the strongest correlation was found between affective commitment, transformational leadership $\left(0,527^{* *}\right)$, and transactional leadership $\left(0,408^{* *}\right)$. Laissez-faire leadership style, according to the research data, is negatively related to affective commitment $\left(-0,209^{* *}\right)$. The continuance commitment is slightly positively related to transformational leadership $\left(0,146^{*}\right)$ and transactional leadership $\left(0,149^{*}\right)$; and has no relationship with laissez-faire leadership $(0,029)$. Normative commitment positively correlates with transformational leadership $\left(0,385^{* *}\right)$ and transactional leadership $\left(0,313^{* *}\right)$. A weak negative correlation was found between normative commitment and a laissez-faire leadership style $\left(-0,162^{*}\right)$.

\begin{tabular}{|l|c|c|c|c|c|}
\hline & Mean & $\begin{array}{c}\text { Affective } \\
\text { commitment }\end{array}$ & $\begin{array}{c}\text { Continuance } \\
\text { commitment }\end{array}$ & $\begin{array}{c}\text { Normative } \\
\text { commitment }\end{array}$ & $\begin{array}{c}\text { Satisfaction } \\
\text { with } \\
\text { immediate } \\
\text { supervisor }\end{array}$ \\
\hline $\begin{array}{l}\text { Transformational } \\
\text { leadership style }\end{array}$ & 7.19 & $0,527^{* *}$ & $0,146^{*}$ & $0,385^{* *}$ & $0,790^{* *}$ \\
\hline $\begin{array}{l}\text { Transactional } \\
\text { leadership style }\end{array}$ & 6.38 & $0,408^{* *}$ & $0,149^{*}$ & $0,313^{* *}$ & $0,586^{* *}$ \\
\hline $\begin{array}{l}\text { Laissez-faire } \\
\text { leadership style }\end{array}$ & 3.57 & $-0,290^{* *}$ & 0,029 & $-0,162^{*}$ & $-0,569^{* *}$ \\
\hline $\begin{array}{l}\text { Affective } \\
\text { commitment }\end{array}$ & 6.83 & 1,000 & $0,341^{* *}$ & $0,591^{* *}$ & $0,471^{* *}$ \\
\hline $\begin{array}{l}\text { Continuance } \\
\text { commitment }\end{array}$ & 5.44 & $0,341^{* *}$ & 1,000 & $0,344^{* *}$ & 0,141 \\
\hline $\begin{array}{l}\text { Normative } \\
\text { commitment }\end{array}$ & 6.62 & $0,591^{* *}$ & $0,344^{* *}$ & 1,000 & $0,343^{* *}$ \\
\hline $\begin{array}{l}\text { Satisfaction with } \\
\text { an immediate } \\
\text { supervisor }\end{array}$ & 7.8 & $0,471^{* *}$ & 0,141 & $0,343^{* *}$ & 1.000 \\
\hline
\end{tabular}

** $p<0.01$

${ }^{*} p<0.05$

Table 1. Rank means and correlations between commitment dimensions, leadership style and satisfaction with an immediate supervisor 
The findings confirm that transformational leadership creates the highest satisfaction with an immediate supervisor $\left(0,790^{* *}\right)$, although a positive medium correlation was found between transactional leadership and satisfaction with an immediate supervisor $\left(0,586^{* *}\right)$. The strongest negative effect on satisfaction with an immediate supervisor is identified in the case of a laissezfaire leadership style $\left(-0,569^{* *}\right)$.

The present study findings report a strong positive relationship between transactional and transformational leadership styles $\left(0,699^{* *}\right)$, a medium negative correlation between transformational and laissez-faire leadership styles $\left(-0,548^{* *}\right)$, and an even weaker negative correlation between transactional and laissez-faire leadership styles $\left(-0,328^{* *}\right)$.

\section{Hypotheses Testing}

The research reported here provides data on the relationships between employee commitment, leadership styles and employees' satisfaction with their immediate supervisor. The first hypothesis anticipated that a transformational leadership style would be an excellent predictor of employee affective commitment. The results supported hypothesis 1 , indicating a $0,527^{* *}$ relationship between the two variables. Thus, hypothesis 1 was supported.

H1:Transformational leadership style is positively related to employee affective commitment was empirically supported.

As anticipated for hypothesis 2, this analysis revealed a positive weak relationship between a transactional leadership style and employee continuance commitment $\left(0,149^{*}\right)$. Hypothesis 2 was partially supported.

H2: A transactional leadership style is positively related to employee continuance commitment.

The transformational leadership style variable was found to have a statistically significant positive effect $\left(0,385^{* *}\right)$ on normative employee commitment. Thus, hypothesis 3 was supported partially.

H3: A transformational leadership style is positively related to employee normative commitment.

As hypothesized, a laissez-faire leadership style is negatively related to employee affective commitment. The study revealed a negative significant association between laissez-faire leadership style and employee affective commitment $\left(-0,290^{* *}\right)$. Hypothesis 4 was supported.

H4: A laissez-faire leadership style is negatively related to employee affective commitment.

The study results show no evidence to support the relationship between transformational leadership and employee continuance commitment. The variables have a positive, albeit very weak relationship $\left(0,146^{*}\right)$. Thus, hypothesis 5 was partially supported.

H5: A transformational leadership style is negatively related to employee continuance commitment.
Consistent with previous findings, satisfaction with an immediate supervisor has positive associations with employees' affective $\left(0,471^{* *}\right)$ and normative $\left(0,343^{* *}\right)$ commitments. Thus both hypotheses 6 and 7 were supported.

H6: Satisfaction with an immediate supervisor is positively related to employees' affective commitment.

H7: Satisfaction with an immediate supervisor $r$ is positively related to employees' normative commitment.

The correlations between employee commitment (affective, continuance, and normative), leadership styles (transformational, transactional, and laissez-faire) and satisfaction with an immediate supervisor are provided in Figure 2.

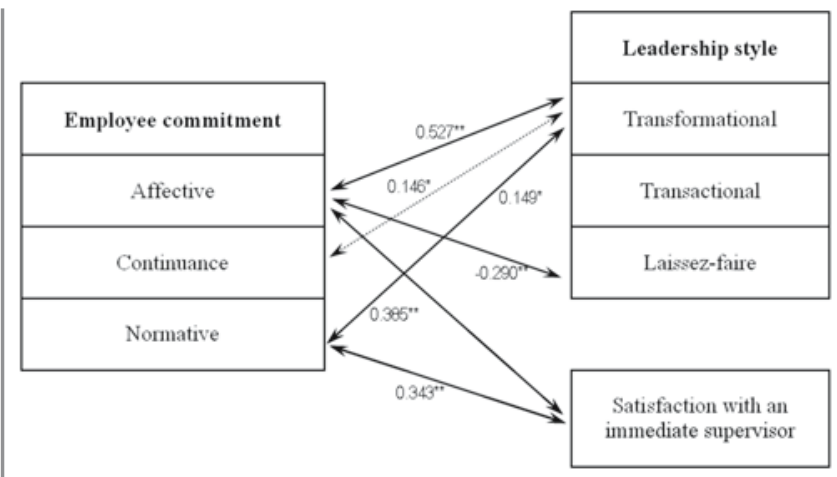

Figure 2. Correlations between employee commitment level, leadership styles, and satisfaction with an immediate supervisor.

\section{Discussion}

The study of leadership styles and employee commitment dimensions - affective, continuance, and normative - in manufacturing firms showed a strong relationship between a transformational leadership style and affective employee commitment, and a less strong relationship of this leadership style with normative employee commitment This study, therefore, supports the suggestions by F. Brown and N. Dodd (2003) that transformational leadership and affective and normative commitment are correlated. However, this study does not support suggestions made by L. Simon (1994) that a transformational leadership style has a negative correlation with continuance commitment. The relationship between a transformational leadership style and continuance commitment exists in Lithuanian enterprises but is not very strong.

Insum, atransformational leadership styleexhibited positive relationships with employee commitment in psychological, value, morale, and economic terms. This is consistent with the suggestions of D.S. Carlson and P.L. Perrewe (1995): "When transformational leadership is established, members of an organization view their own values and benefit as those of the organization." Given that a transformational leadership style is often associated with emotional aspects, 
it is not surprising that transformational leadership has the greatest correlation with affective employee commitment Consistent with previous studies, transformational leadership has positive associations with commitment dimensions (Lee, 2005). As a transformational leader helps followers develop beyond their potential and satisfy their higher order needs, $\mathrm{s} /$ he is likely to gain their followers' commitment to the organization (Rowden, 2000). Similar to the findings of J. Lee (2005) and P. Bycio et al. (1995), transformational leadership, according to the results of this research, has a positive but lower relationship with employees' normative commitment.

A transactional leadership style also relates positively to affective and normative employees' commitment This finding indicates that leaders' and followers' associations, as well as in the case of transformational leadership, affects employees' emotional identification with an organization and relates to their feelings of responsibility. This finding contradicts F. Brown and N. Dodd (1999), whose empirically supported arguments stated that transactional leadership has a negative association with affective and normative commitments. An explanation of this finding may be due to the characteristics of the research sample used by $F$. Brown and N. Dodd (1999): they investigated employees in US municipalities. When compared to transformational leadership, transactional leadership is less effective in affecting employees' affective and normative commitments and similarlyaffectingemployees' continuancecommitment. Compared to transformational leadership, transactional leadership associated less significantly with all employees' commitment dimensions.

Employee satisfaction with their immediate supervisors in Lithuanian manufacturing organizations is reported to have significant effects on employees' affective and normative commitments. The study's findings support the results of A.E. Reichers (1985) and H.S. Becker (1992), which proved that employee commitment "hides" behind satisfaction with a leader's goals and values. J.P. Meyer and N.J. Allen (1997) also support the idea that it is likely that employees' commitment to their organization is the product of employees' commitment to their leader.

Owing to the transactional nature of exchange between transactional leaders and employees, transactional leadership has less significant associations with employees' commitment The association with employees' continuance commitment in both leadership behavior cases is very weak. This can be attributed to a continuance commitment and economic benefit interlinks. Laissez-faire leadership, given its nonintervening nature, has negative consequences on all employee commitment dimensions and satisfaction with an immediate supervisor. The results are consistent with the literature indicating that laissez-faire leadership does not yield positive organizational behavior and produces negative impacts on followers' respect for their supervisors (Lee, 2005).
The findings of this study reveal that transformational leadership has positive associations with the dimensions of employee commitment and satisfaction with an immediate supervisor, and that transformational and transactional leadershipareimportantin relationtofollowers' organizational commitment Such findings clearly indicate the important role of transformational leadership, and the importance for organizations to nurture transformational leadership qualities among their leaders.

\section{Conclusion}

The results of this study confirm earlier findings on the relationship between leadership style and commitment dimensions (affective, normative and laissez-faire) and the positive association between satisfaction with an immediate supervisor and commitment The important finding of this study is that transformational leadership style has a greater influence on affective employee commitment than on normative employee commitment It can be suggested that a transformational leadership style has positive associations with employees' commitment in psychological, value, morale and economic terms. This finding also led us to conclude that transformational leadership is a better predictor of employee commitment In a similar manner, transactional leadership style is related to both affective and normative commitment. Transactional interaction between a supervisor and an employee influences employees' affective identification with an organization and their feelings of responsibility. According to the findings, transformational and transactional leadership styles have a very weak influence on continuance commitment This evidence lends support to the fact that continuance commitment refers to commitment based on the costs that an employee associates with economic benefit. It is also found that satisfaction with an immediate supervisor in Lithuania manufacturing companies relates positively with employees' affective commitment Thus, in high quality exchanges characterized by affective commitment, satisfaction and professional respect, leaders create positive experiences for their employees. A laissez-faire leadership style was found to be negatively associated with employees' commitment and may intervene in the work affairs of leaderemployee interaction or inhibit the successful development of an organization.

\section{Implications for Future Research}

In future research, it would be interesting to assess causal relationships and replicate this study in a longitudinal design to determine if the findings tested are likely to be sustained. Future studies can benefit by including leadership styles and other variables such as loyalty or selfefficacy beliefs in determining employee commitment. Comparisons can also be made between the service and manufacturing industries. [a. 


\section{References}

Allen, N. J., \& Meyer, J. P. (1990). The measurement and variables associated with affective, continuance and normative commitment to the organization. // Joumal of occupational psychology, 63.

Alley, W.and Gould, R.B. (1975). FeasibilityofEstimatingPersonnel Tumover from Survey Data: A Longitudinal Study, Air Force Human Resources Laboratory.//Brooke AirForce Base, TX.

Antonakis, J. (2001). The validity of the transformational, transactional, and laissez-faire leadership model as measured by the Multifactor Leadership Questionnaire (MLQ 5X).// Walden University, Minneapolis, MN.

Avolio, B. J., \& Bass, B. M. (1991). The full range of leadership development basic and advanced manuals. // NY: Bass, Avolio \& Associates.

Avolio, B.J., Bass, B.M. \& Jung, D.I. (1999). Re-examining the components of transformational and transactional leadership using the Multifactor Leadership Questionnaire.// Joumal of Occupational and Organizational Psychology, 72.

Avolio, B. J., \& Bass, B. M. (2002).Manual for the Multifactor Leadership Questionnaire (Form 5X).// Walden University, Mineapolis, MN.

Bass, B. M. (1985). Leadership and performance beyond expectations. //NY: Harper \& Row.

Bass, B.M. (1990). From Transactional to Transformational Leadership: Learning to share a Vision.// Organizational Dynamics, 18(3)

Bass, B.M. \& Avolio, B.J. (1993). Transformational leadership: a response to critiques. // Leadership Theory and Research: perspectives and Directions. Academic Press, San Diego, CA.

Becker, H. S. (1960). Notes on the concept of commitment // American joumal of sociology, 66, 32-40.

Becker, T. E. (1992, May). Foci and bases of commitment are they distinctionsworth making?//Academy ofManagement Joumal, 35 .

Bycio, P., Hackett, R. D., \& Allen, J. (1995). Further assessments of Bass's conceptualization of transactional and transformational leadership. // Joumal of applied psychology, 80.

Brief, A. P., Aldag, R. J., \& Wallden, R. A. (1976). Correlates of supervisory style among policemen. // Criminal justice and behavior, 3 .
Brown, F., \& Dodd, N. (1999). Rally the troops of make the trains run on time. //Leadership and organizational development, 20.

Bums, J. M. (1978). Leadership. //NY: Harper \& Row.

Carlson, D. S. \& Perrewe, P. L. (1995). // Institutionalization of organizational ethics through transformational leadership. Joumal of Business ethics, 14.

Chemers, M. M. (1997). An integrative theory of leadership. // Mahwah, NJ: Lawrence Eribaum associates.

Deluga, R.J. (1992). The relationship ofleader-member exchange with laissez-faire, transactional, transformational leadership in naval environments.// Impact of Leadership. Centre of Creative Leadership, Greensboro, NC.

Glisson, C. \& Durick, M. (1988). Predictors of job satisfaction and organizational commitment in human service organizations. // Administrative Science Quarterly, 33.

Hamton, R., Dubinsky, A.J. and Skinner, S.J. (1986). A model of sales supervisor leadership behavior and retail salespeople'sjobrelated outcomes.//Academy ofMarketing Science, Vol. 14.

Hartog, D. N., Muijen, J. J., \& Koopman, P. L. (1997). Joumal of Occupational \& Organizational Psychology, 70.

Howell, J.M. and Avolio, B.J. (1993). Transformational leadership, transactional leadership, locus pf control, and support for innovation: key predictors of consolidated business unit performance.//Joumal of Applied Psychology, Vol. 78.

Howell, J.M. and Hall-Merenda, KE. (1999). The ties that bind: the impact of leader-member exchange, transformational and transactional leadership, ands distance on predicting follower performance.// Joumal of Applied Psychology, Vol. 84.

Hunt, J.G. and Liesbscher, V.K.C. (1973). Leadership preference, leadership behavior and employee satisfaction.//Organizational Behavior and Human Performance, Vol.9.

Jaros, S. J., Jermier, J. M., Koehler, J. W., \& Sincich, T. (1993, May). Effects of continuance, affective and moral commitment on the withdrawal processand evaluation. //Academy ofManagement Joumal, 36.

Jaussi, K.S. (2007). Attitudinal commitment A three-dimensional construct //Joumal of Occupational and Organizational Psychology, 80.

Kraut, A.I. (1970). The Prediction of employee Tumover by Employee Attitudes.// American Psychological Association, Boston, MA. 
Lee, J. (2004). Effectsofleadership and leader-member exchange on commitment// Leadership and Organization Development Joumal, Vol.26.

Meyer, J. P., \& Allen, N. J. (1997). Commitment in the workplace: Theory, research and application. //London: Sage publications.

Meyer, J. P., \& Allen, N. J. (1984). Testing the "side-bet theory" of organizational commitment Some methodological consederations. // Joumal of Applied Psychology, 69.

Meyer, J. P. \& Allen, N. J. (1993). Commitmentto organization and occupations: extension of a three-component model. // Joumal of Applied Psychology, 78(4).

Meyer J. P. \& Herscovich, L. (2001). Commitmentin the workplace: toward a general model. // Human resources managment review, 11, 299-326.

Michael, C. E. \& Sector, P. E. (1982). Causes of employee tumover. Joumal of Applied Psychology, 67.

Morris, J. \& Steers, R. M. (1980). Structural influences on organizational commitment // Joumal of Vocational Behavior, 17.

Mowday, R.T.,Steers, R.M.\&Porter,L.W.(1979). Themeasurement oforganizational commitment // Joumal ofVocational Behavior, 14.

Newman, J.E. (1974). Predicting absenteeism and tumover. a field comparison of Fishbein's model and traditional job attitude measures.// Joumal of Applied Psychology, Vol. 59.

O'Reilley, C.A. and Roberts, K.H. (1978). Superior influence and subordinates' mobility aspiration asmoderatorsof consideration and initiating structure.// Joumal of Applied Psychology, Vol.63.

O'Reilly, C., \& Chatman, J. (1986). Organizational commitment and psychological attachment the effects of compliance, identification and intemalization on prosocial behavior. // Joumal of Applied Psychology, 71.

Owen, H., Hodgson, V., \& Gazzard, N. (2004). The leadership manual: your complete guide to effective leadership. //Pearson Professional Education.

Parasuraman, S., \& Nachman, S. (1987). Correlates of organizational and professional commitment // Group and Organizational Studies, 12.

Porter, L. W., Steers, R., Mowday, R. \& Boulian, P. (1974). Organizational commitment,job satisfaction and tumoveramong psychiatric technicians. // Joumal of Applied Psychology, 74.
Porter. L.W., Campon, W.J. and Smith, F.J. (1976). Organizational Commitment and managerial tumover. a longitudinal study.// Organizational Behavior and Human Performance, Vol. 9.

Randall, D. M. \& O'Driscoll, M. P. (1997, May). Affective versus calculative commitment human resource implications. // Joumal of Social Psychology, 137.

Reichers, A. E. (1985). A review and conceptualization of organizational commitment // Academy of Management Review, 10.

Romzek, B. S. (1990). Employee investment and commitment the ties that bind. //Public Administration review, 50, 374-381.

Rowden, R. W. (1999). The relationship between charismatic leadership behaviors and organizational commitment// The Leadership and Organization Development Joumal, 21/1.

Rowden, R.W. (2000). The relationship between charismatic leadership behaviors and organizational commitment// The Leadership \& Organization Development Joumal, 21/1.

Salancik,G. (1977).Commitmentand thecontroloforganizational behavior and belief.//St Clare Press, Chicago, IL.

Seltcer, J. and Bass, B.M. (1990). Transformational leadership: beyond initiation and consideration.// Joumal of Management, Vo.16.

Simon, L. (1994). Trustin leadership:Itsdimensionsand mediating role. // Kansas state university, Manhattan, KS.

Stogdill, R. M. (1974). Handbook of leadership. // NY: Appleton century-crofts.

Suliman, A. M. \& Isles, P. A. (2000). The multidimensional nature of organizational commitment in a non-westem context // Joumal ofmanagement development, 19(1).

Taylor, S. (1998). Employee resourcing. // London: Institute of personnel and development

Walton, R. E. (1985). From control to commitment in the workplace. //Harvard Business Review, 63.

Ward, E. A. \& Davis, E. (1995, Summer). The effect of benefit satisfaction on organizational commitment // Compensation \& BenefitsManagement

Yukil, G.A. (1989). Leadership in Organizations.// Prentice-Hall, Englewood Cliffs, New Jersey. 
